www.jmscr.igmpublication.org Impact Factor 5.244

Index Copernicus Value: 5.88 ISSN (e)-2347-176x ISSN (p) 2455-0450 crossref DOI:_http://dx.doi.org/10.18535/jmscr/v4i5.47

\title{
Assessment of Blood Iron and Manganese on Artesant Welders Exposed to Welding Fumes
}

\author{
Authors \\ Torka N. Sordum ${ }^{1}$, Ndokiari Boisa ${ }^{2}$ \\ ${ }^{1}$ Chemical Pathology, Department of Medical Laboratory Science, Rivers State University of Science and \\ Technology Port Harcourt. \\ ${ }^{2}$ Department of Chemistry, Rivers State University of Science and Technology Port Harcourt \\ Corresponding Author \\ Torka N. Sordum \\ +2348063480511,Email:torka@yahoo.com
}

\begin{abstract}
Whole blood iron and manganese levels in artesant welders control subjects were invstigated. Five (5ml) blood samples were collected via venepuncture from thirty (35) welders and twenty five (25) control subjects after their voluntary consent. Samples were digested using standard method. Aliquots of digested samples were assessed for Mn and Fe content with Atomic Absorption Spectrophotometer. The data obtained were expressed as the mean \pm Standard Deviation. Independent sample $t$ - test was conducted with the means with

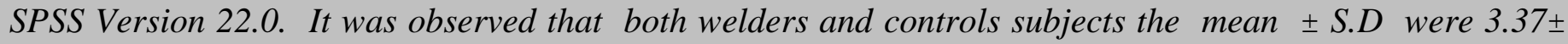
$1.34 \mu \mathrm{g} / \mathrm{l}$ and $3.34 \pm 1.43 \mu \mathrm{g} / \mathrm{l}$ respectively. Means and standard deviations of blood manganese $(M n-B)$ levels in welders and controls subjects were $3.37 \pm 1.34 \mu \mathrm{g} / \mathrm{l}$ and $3.34 \pm 1.43 \mu \mathrm{g} / \mathrm{l}$ respectively. Means and standard deviations blood iron (Fe-B) levels for welders and control subjects were $410 \pm 104 \mu \mathrm{g} / \mathrm{dl}$ and 166 $\pm 37 \mu \mathrm{g} / \mathrm{dl}$ respectively. Significant difference at $p<0.001$ was observed when means for test and control subjects were compared. There were no correlations between Mn-B and Fe-B levels of welders with duration of exposure and age. This study has revealed that welders in Elekahia Estate, Community and railway off Trans -Amadi Layout of Port Harcourt have normal Mn-B level with non welders while there $\mathrm{Fe}-\mathrm{B}$ level is exceptionaly high than non welders. Exposure to iron, may cause iron overload (siderosis) and iron accumulation in liver, heart, and kidney leading to hepatomegaly, myocardial siderosis and metabolic acidosis.
\end{abstract}

Keywords: Iron; Manganese; Welder; Duration of exposure; Welding fume; Welding electrode.

\section{INTRODUCTION}

Iron $(\mathrm{Fe})$ is a mineral substance that is abundant in the hemoglobin of red blood cells and in the myoglobin of muscle cells. Iron catalyses the formation of vitamin $\mathrm{A}$ and is incorporated in some enzymes ${ }^{[1]}$. The human body contains approximately $20 \mathrm{mg}$ of manganese (Mn), they are found in the bones, kidney and liver
${ }^{[2]}$. Though manganese is an essential trace element for human survival, it is also toxic when in high concentration in human body Manganese is a mineral element that is both nutritionally essential and potentially toxic. Manganese is important in protein, carbohydrate, lipid and cholesterol metabolism. Manganese is essential for the development of 
bone ${ }^{[3]}$. Manganese is applied in the production of carbon steel, high temperature steel, cast iron and super alloy. Manganese oxide is used in the production of dry cell battery, fertilizers, pesticides, livestock nutritional supplement, glass, matches, ceramics and welding rod ${ }^{[4]}$.Welding rods used for different classes of welding have been suggested to consist of Iron and traces of Manganese. Manganese and iron dust is generated during welding process can be inhaled by artesants involved the welding process. During welding these chemicals can also settle on surfaces be resuspended at later dates. And the amount of manganese produced depends on the welding wire, welding current/voltage, electrode type and base metal. Welding significantly increases exposure to manganese fume ${ }^{[5],[6]}$. Prolonged inhalation of dust and fume containing manganese is of a major concern, and high body burden may cause manganism, low libido and impotency in male welders ${ }^{[7]}$. Environmental and occupational exposure to manganese also causes cognitive, neuropsychological and neuro-behaviour, [8], [9] Exposure to low manganese levels may cause fatigue, glucose intolerance, blood clothing and skin problems, skeleton disorder, birth defect, changes of hair colour and neurological symptom ${ }^{[10]}$. The normal blood manganese (Mn-B) level is $0.6-2.4 \mu \mathrm{g} / \mathrm{l}$. While that of blood iron (Fe-B) level is $(55-160 \mu \mathrm{g} / \mathrm{dl})$. Excess blood iron (iron toxicity or siderosis), called iron overload, usually leads to Iron accumulation in the liver, heart, and kidney causing hepatomegaly, myocardial siderosis and metabolic acidosis ${ }^{[11]}$.

Published data on human exposure to Iron and Manganese and associated health effects is presently scarce. Welding artesants in developing countries are not aware of their possible exposure to Iron and Manganese fume while carrying out their work. Therefore, this research was conducted to assess Iron and Manganese level in the blood of welding artesants.

\section{MATERIALS AND METHODS}

\section{Study Area/ Materials}

The study was carried out on welders within Elekahia Housing Estate, Elekahia community and Elekahia Railway in Port Harcourt, Rivers State, Nigeria. The welders selected for this study operated outside confined spaces and used the gauge $10-12$ electrode.

Materials used were, $5 \mathrm{mls}$ syringe and needle, Pasteur pipette, automated micropipette, lithium heparin container, plain containers, sterile urine container, cotton wool, methylated spirit, tourniquet, hand gloves, beaker, volumetric flasks, sample rack, test-tubes, cover glasses, funnel, wash bottle.

Equipment used were Atomic Absorption Spectrophotometer (AAS), centrifuge, refrigerator, hot air oven, hot plate. Solutions used were deionized water, perchloric acid, nitric acid, sulphuric acid, manganese and and iron standard.

\section{Collection of Blood Sample}

Five (5) ml blood samples were collected via venepuncture from thirty-five (35) welders and twenty-five (25) non welders who gave their concent. The blood samples were stored in the fridge. 7

\section{Subject Selection}

Test subjects were included on the basis that they have been involved in welding activity for atleast five years. Only male subjects were selected because the profession is dominated by them. The thirty-five (35) welders willingly gave their blood samples. Control subjects (25) were selected on the basis that they have not been involved in any form of welding activity before. The welders average working experience is 14.4 years. Mean age for welders was 33.8 years, while that of non welder was 30.6 years. Subjects were grouped as Stick (SMAW), Structural (SAW), Argon (GMAW), scumcural (SCUW) welders and control (CTRL). 


\section{Treatment of Sample}

\section{Sample digestion}

Prior to sample digestion time, all the test tubes, $100 \mathrm{ml}$ flasks, funnels and measuring cylinders were acid washed and dried in the hot air oven. To ensure they were free of contaminant of any kind. Digestion of sample was done using oxidizing acid mixture of nitric, perchloric and sulfuric acid in 3:1:1 v/v/v ratio ${ }^{[12]}$. About $9 \mathrm{ml}$ of the mixture was added to $1 \mathrm{ml}$ of whole blood, mixed, placed on hotplate and digested for $60-$ 90 minute at $200^{\circ} \mathrm{C}$. At the end of digestion process the solution was allowed to cool and the resulting mixture filtered into $100 \mathrm{ml}$ volumetric flask. The residue was washed with deionized into the $100 \mathrm{~mL}$ flask and the volume of the flask made to mark with deionized water.

\section{Analysis}

AAS calibration curves were established using absorbance from five freshly prepared manganese and iron standard solutions $(1.0 \mathrm{~mL}$ to $5.0 \mathrm{~mL}$ ). $10 \mathrm{ug} / \mathrm{L}$ Aliquot of the digested samples were analysed with AAS using the manganese and iron lamps. The molar absorptivity obtained from slope of graph plotted was used to determine the concentration manganese and iron in the unknown samples based on Beer-Lambert law.

\section{Statistical Analysis}

The data obtained during interview sessions with study subjects and results were reviewed, and expressed as the mean, mean \pm standard deviation. Differences between two means were analysed using independent sample t-test with the Statistical Package for Social Sciences (SPSS) version 22.0.

\section{RESULTS}

Means and standard deviations of blood Manganese (Mn-B) levels in welders and controls subjects were $3.37 \pm 1.34 \mu \mathrm{g} / \mathrm{l}$ and 3.34 $\pm 1.43 \mu \mathrm{g} / \mathrm{l}$ respectively (Table 3.1 ). The mean values for welders and control were not significantly different when compared $(\mathrm{t}=$ 0.088, p =0.930) (Table 3.1). Means and standard deviations blood iron (Fe-B) levels for welders and control subjects were $410 \pm 104$ $\mu \mathrm{g} / \mathrm{dl}$ and $166 \pm 37 \mu \mathrm{g} / \mathrm{dl}$ respectively (Table 3.2). A significant difference $(\mathrm{t}=-11.283, \mathrm{p}=$ 0.000 ) was observed when mean values for both subjects were compared.

Means and standard deviations of Mn-B levels for Stick, Structural, Argon, scumcural welders and control were $3.34 \pm 1.6 \mu \mathrm{g} / \mathrm{L}, 3.40 \pm 1.35$ $\mu \mathrm{g} / \mathrm{L}, 3.07 \pm 1.33 \mu \mathrm{g} / \mathrm{L}, 4.1 \pm 0.14 \mu \mathrm{g} / \mathrm{L}$, and $3.34 \pm 0.27 \mu \mathrm{g} / \mathrm{L}$, respectively (Table 3.3). Means and standard deviations of Fe-B levels for Stick, Structural, Argon, scumcural welders and control were $418 \pm 104 \mu \mathrm{g} / \mathrm{dl}, 415 \pm 104 \mu \mathrm{g} / \mathrm{dl}$, $415 \pm 132 \mu \mathrm{g} / \mathrm{dl}, 345 \pm 28 \mu \mathrm{g} / \mathrm{dl}, 401 \pm 107 \mu \mathrm{g} / \mathrm{dl}$ and $166 \pm 37 \mu \mathrm{g} / \mathrm{dl}$, respectively (Table 3.4). Using pearson correlation, the correlation and $\mathrm{p}$ values between Mn-B level of welders, duration of exposure and age are $(\mathrm{r}=-004, \mathrm{p}=0.980)$ and $(\mathrm{r}=-174, \mathrm{p}=-311)$, respectively (Table 3.5). Similarly there was a negative correlation and no significant differences between welders Fe-B levels and duration of exposure $(r=-204, p$ $=-246)$ and between age and Fe-B levels $(\mathrm{r}=-$ $233, \mathrm{p}=-172)$.

Table 3.1: Blood Manganese Level in $\mu \mathrm{g} / 1$ in Subjects and controls

\begin{tabular}{|l|l|l|l|}
\hline Variables & Numbers & Mean \pm S.D & p-Value \\
\hline Subjects & 35 & $3.37 \pm 1.34$ & $\mathrm{p}<.001$ \\
\hline Controls & 25 & $3.34 \pm 1.47$ & \\
\hline
\end{tabular}


Table: 3.2: Blood Iron concentration in $\mu \mathrm{g} / \mathrm{dl}$ in subjects and controls.

\begin{tabular}{|l|l|l|l|}
\hline Variables & Numbers & Mean \pm S.D & p-Value \\
\hline Subjects & 35 & $410 \pm 104$ & $\mathrm{p}<.001$ \\
\hline Controls & 25 & $166 \pm 38$, & \\
\hline
\end{tabular}

Table 3.3: Group presentation of various Mn-B Level $(\mu \mathrm{g} / \mathrm{l})$ in subjects.

\begin{tabular}{|l|l|l|l|l|}
\hline Classes & $\mathrm{N}$ & Min & Max & Mean \pm S.D \\
\hline SMAW & 24 & 1.40 & 9.10 & $3.34 \pm 1.61$ \\
\hline SAW & 6 & 2.10 & 5.90 & $3.40 \pm 1.35$ \\
\hline GMAW & 3 & 1.60 & 4.20 & $3.07 \pm 1.33$ \\
\hline SCU W & 2 & 4.00 & 4.20 & $4.1 \pm 0.14$ \\
\hline CTRL & 25 & 1.2 & 7.00 & $3.34 \pm 0.27$ \\
\hline
\end{tabular}

Table 3.4: Group presentation of various Fe-B Level $(\mu \mathrm{g} / \mathrm{dl})$ in subjects and control.

\begin{tabular}{|l|l|l|l|l|}
\hline Classes & $\mathrm{N}$ & Min & Max & Mean \pm S.D \\
\hline SMAW & 24 & 272 & 662 & $418 \pm 104$ \\
\hline SAW & 6 & 273 & 616 & $415 \pm 132$ \\
\hline GMAW & 3 & 324 & 366 & $345 \pm 28$ \\
\hline SCU W & 2 & 324 & 478 & $401 \pm 109$ \\
\hline CTRL & 25 & 108 & 256 & $166 \pm 37$ \\
\hline
\end{tabular}

Key:

SMAW: Stick Metal Arc Welding.

SCU-W : Scumcural Welding.

SAW : Structural Arc Welding

CTRL: Control

GMAW: Gas (Argon) Metal Arc Welding

Table 3.5: Pearson correlation

\begin{tabular}{|l|l|l|}
\hline Variables & Duration of Exposure(r) & Welders's Age $(\mathrm{r})$ \\
\hline Mn-B level in $\mu \mathrm{g} / \mathrm{l}$ & -004 & -174 \\
\hline & -980 & -311 \\
\hline $\mathrm{N}$ & 34 & 35 \\
\hline Fe-B level in $\mu \mathrm{g} / \mathrm{dl}$ & -204 & -233 \\
\hline & -246 & -172 \\
\hline $\mathrm{N}$ & 34 & 35 \\
\hline
\end{tabular}

\section{DISCUSSION}

The results obtained from this study showed no significant difference in mean Mn-B levels of both welders and controls in Table 3.1. This may be due to the absence of recent exposure to welding fume by welders recruted for this study. This suggestion is in agreement with the work of [13] that revealed that Mn-B level above normal reference value $(0.6-2.3 \mu \mathrm{g} / \mathrm{l})$ suggest recent exposure. In a study ${ }^{[8,14]}$ that indicated high levels of Mn-B in welders the elevated levels were suggested to be due very recent exposures to welding fume. A few studies [e.g.14, 15] have concluded that higher levels of Mn-B could be a maker for recent exposure to manganese in welders.

The low Mn-B levels observed for the exposed group in this study may be due the fact that all the welders involved in this studies were conducting their welding out-door (not in confined space). In such borderless environment the generated metallic fumes diffuses off spontaneneously. Our 
suggestion relating todiffusion of generated fumes is consistent with with the work of ${ }^{[16]}$ on doseeffect relationship between Manganese exposure and neurological, neurophychological and pulmonary funtion in confined space welders. At the end of study Mn-B level was greater than ten (10) $\mu \mathrm{g} / \mathrm{l}$.

Some other reasons for low Mn-B may be due to welding process, flux and based metal, electrode diameter and unsteady power/current supply. Also, this study demography shows that majority of welders (about 68.6\%) used were engaged in stick welding process, the coating on the welding rod materials helps to minimize impurities. The study of ${ }^{[17]}$ revealed that level of Manganese generated depended on the welding process.

The low Mn-B observed in this study may also depend availability of electric power to welders, since most of welders depended public power supply which is presently not regular in Port Harcourt. So there is no steady current during welding process, therefore fewer fumes are generated.

The significant differerence between blood Iron of welders and control, $(410 \pm 104$ and $166 \pm 37$ at $p$ $<0.001)$. This is consistent with the work of ${ }^{[18]}$, using the data obtained by Korean National Health and Nutrition Exam Survey (KNHANES) of 2008. They revealed that manganese level decreased steadily with higher blood levels and reached it a plateau around Iron concentration of $75 \mu \mathrm{g} / \mathrm{L}$.

The study of ${ }^{[16]}$ on confined space bridge welders revealed that blood Iron level was $469-2016 \mu \mathrm{g} /$ L. The work of ${ }^{[19]}$ which revealed that blood manganese level may be lowered because both shared the up-regulation mechanism of gastrointestinal absorption ${ }^{[16]}$.The study of ${ }^{[20]}$ also revealed that there is difference between blood half -life and tissue half-life of manganese which is two (2) hours and half-life of manganese from inorganic source which is fifty (50) to seventy (70) days.

\section{CONCLUSION}

The results obtained from this study on welders in Elekahia Estate, and railway (off Trans-Amadi Layout) revealed no significant different in blood Manganese level of both welders and controls whilts the mean Fe-B level was significantly higher in welders than controls. This result indicates that iron is the major contaminant generated during welding. Since Iron compete with manganese during gastro- intestinal absorption, increased Fe-B may be responsible for low Mn-B. If welders are exposed to hih levels of iron fumes, they may be prone to iron overload (siderosis) which may lead to its accumulation in liver, heart, and kidney causing hepatomegaly, myocardial siderosis and metabolic acidosis respectively.

\section{ACKNOWLEDGMENT}

I am grateful to Dr. N. Boisa for the design and supervision of this study. I also appreciate $\mathrm{Mr}$. Sordum Neebee for funding the project. Special appreciation to Mr Obisike, U.A. and Dr. Holy Brown for thier technical support.

\section{REFERENCES}

1. Carl, A., Burtis, E. \& Ashwood, R. (2001). Tietz fundamentals of clinical chemistry ( $5^{\text {th }}$ edition) pp. 990-991.

2. Keen, C..L., Ehsunsa, J. L, \&Watson, M. H, (2000).. Nutritional aspects Manganese from Experimental Studies. Neurotoxicology, 20(3), 213-223.

3. Santamaria, A. B. \& Sulsky, S. I. (2010). Risk assessment of an essential element manganese. Journal Toxicology Environmental Health, 73, 128 - 155

4. Barce, D. G., (1999). Manganese. Journal of Toxicology, 37, 293- 307.

5. Antonini, J. M., Santamaria, A. B., Jenkins, N. T., Albini, E. \& Lacchini, R. (2006). Fate of manganese associated with the inhalation of welding fumes: Potential neurological effects neurotoxicology; 27, $304-310$. 
6. Crossgrove, J.R., \& Zheng, W., (2004). Review of Manganese Toxicity upon overexposure, NMR Biomedical Jou, 17, 8- 14

7. Agency for Toxic Substances \& Disease Registry (2012). Toxicological Profile for Manganese. Journal Toxicology of Environmental Health, 3 (1), 28 - 55.

8. Ellingsen, D. G., Kon, Stantmov, R., BastPettersen, R., Merkerfera, L., Cheshhan, M. \& Thomassen, Y. (2008). A neurobehavioural study of current ano tonner welders expose to manganese. Neurotoxicology, 29, 48 - 59.

9. Chang, Y., Lee. J. J., Seo, J. H., Song, H. J., Kim, J. H. \& Baes, J. (2010). Altered working memory process in the manganese exposed brain. Neurology,53(4),1279 1285 .

10. Blaurock-Busch, E. (1999). Mineral and trace element analysis. Laboratory and Clinical Application Journal.5(1), 45 - 76.

11. Annual Report of the American Association of Poison Control Centers (AAPCC) National poison data system report.

12. Oruambo, I. F., Brown, H. \& Okeh, C. (2013). Correlation between exposure to toxic heavy metals in fish, sediment and drinking water, and high incidence of parasitatals enlargement in two states of the Niger Delta, Nigeria. Biochemistry and Biotechnology Research, 2(1), 1 - 5 .

13. Levy, B. S. \& Nassetta, W. J. (2003). Neurologic effects of manganese in human. A review: International Journal Occupation Environmental Health, 9(2), $153-163$.

14. Ling, L., Long-Lian, E. Zhang, S., Jane, L., Wennis, G., Wannian, L. \& Wei, Z. (2005). Alteration of serum concentration of Manganese, Iron, Ferrtin and transferrin. Neurotixicology, 26(2), 257- 265

15. Li, G. J., Zhang, L., Lu, L., Wu, P. \& Zheny, W. (2004). Occupational exposure to welding fume among welders alterations of manganese, iron, zinc, copper, and lead in body fluid and the oxidative stress status. Journal of Occupational Environmental Medicine,46, 241 - 248.

16. Rosemeria, M., Bowler, Harry, A., Roels, S. N., Managa, D., Emily, D., Robert, P., William, K., Russell, P., Bouler, D. M., Manyse, B., Donald, S., Roberto, G. \& Richard, L. D. (2007). Dose-effect relationships between manganese exposure and neurological, neuropsychological and pulmonary function in confined space bridge welders. Occupational Environmental Medicine, 64, 167 - 177.

17. Smargiass, I. A. \& Mutti, B. (2000). Assessment of exposure to manganese in welding operation during the assembly of heavy excavation machinery accessories. Application Occupational Environment, 15, $746-750$.

18. Kim, Y. and Lee, B. K. (2012). Iron deficiency instead blood manganese level in the Korean general population according to Knhanes. Neurotoxicology, 33(3), $401-405$.

19. Davis, C. D., Wolf, T. J. \& Greoger, J. L. (1992). Varying levels of manganese and iron affect absorption and gut endogenous losses of manganese by rats. Journal of Nutrition, 120(6), 1300 - 1308.

20. Zheng, W. (2001). Neurotoxicology of the brain system, new implication. Journal Toxicology Clinical Toxicology, 39, 711 719. 